\title{
Walras and Contemporary Financial-Economic Crisis
}

\author{
Ezra Davar \\ Independent Researcher, Netanya, Israel \\ Email: ezra.davar@gmail.com
}

Received 10 April 2014; revised 10 May 2014; accepted 20 May 2014

Copyright (C) 2014 by author and Scientific Research Publishing Inc.

This work is licensed under the Creative Commons Attribution International License (CC BY). http://creativecommons.org/licenses/by/4.0/

c) (i) Open Access

\begin{abstract}
This paper shows that one of crucial causes of contemporary financial-economic crisis is an abandonment of the classic and Walras's theories, in particular the monetary theory. Therefore, it discusses three fundamental differences between Walras's and modern economists' approaches: 1) the relationship between theory and reality; 2) the use of mathematics in economic theory; and 3) the monetary theory. The paper demonstrates that the modern approach is even incompatible with hypothetical economics because of unrealistic assumptions, for example, there is only one type of money-fiat money; whilst Walras's approach applies well to its era's reality.
\end{abstract}

\section{Keywords}

Financial-Economic Crisis, Walras's and Modern Approaches, The Use of Mathematics in Economic Theory, Money Commodity, Fiat Money

\section{Introduction}

A large contributing factor of the contemporary economic-financial crisis is the appalling state of Economics as a science-deep in a crisis of its own since the beginning of the previous century (since post-neoclassical economic (Walras, Marshall)). This is in complete contrast with the vast improvements in an individual's wealth and productivity in the last century.

Despite of, and maybe perhaps because of the continuously growing amount of published books and papers the situation is becoming increasingly critical. The main reason for this crisis lies in the misunderstanding and misinterpretation of the classics, especially of Walras's theory [1]; therefore the classics' and Walras's theories, the monetary theory in particular, has been abandoning. At the same time, modern economic literature is very "technical" (mathematical). These mathematically based assumptions nevertheless divorce the consequent theory from the real world. This trend is a violation of the crucial condition of classical economic methodology, 
namely, the reciprocity between theory and reality.

Walras was the first who used mathematics to describe interdependence between various parts of whole economy. His use of mathematics is both effective and impressive, and is based on the latest achievements of his time while trying to explore a new direction. For example, Walras's mathematical model for the economy of individual (micro model) is significant achievement and it is the best model to this day. Also, Walras's unique method of equilibrium establishment for macro model, namely, iterative process - tâtonnement, allowed him transforming the disequilibrium state into the equilibrium state; and by means of that the problem of solution of the equation system where the number of unknowns is large than the number of independent equations is overcame. And, these alls before much more than century! Walras's vision was that "Then mathematical economics will rank the mathematical sciences of astronomy and mechanics; and on that day justice will be done our work” ([2], pp. 47-48).

This is opposite of the modern mathematician-economists asserting that Walras's mathematics is primitive, clumsy, dubious, and even incorrect; and by this they have been trying to delegitimate Walras's mathematical achievements. Almost every author who has written about Walras and his economics has felt obliged to emphasize this fact.

Whilst, modern mathematical models of economics and financial sectors are generally separated and are very complicate but majority of them are weakly connected with reality, for example: modern general equilibrium theory [3] [4]. Instead of gradually updating some of the Walrasian old-fashion assumptions by new ones that are compatible with contemporary economics modern general equilibrium theory has been rediscovering and using almost all of Walras's assumptions; moreover, new, unrealistic assumptions were introduced, making modern economic theory incompatible to reality. Post-Walras's economists ignore Walras's less known assumptions and blame him for disregarding the problem of equilibrium existence, uniqueness and stability and comparative-static. Therefore, their main objective since the beginning of the 20th century was the rigorous proof of equilibrium existence. However, this proof was based on unrealistic assumptions and along the road the goal of economics was lost.

Classics considered money theory as a central and non-separate from the economic one and have discussed their reciprocal influence. Schumpeter stated that Walras "created the modern theory of money. In fact, his theory of money and credit is simply part of this general theory of economic equilibrium” ([5], p. 1082); see also [6] [7].

Majority of economists since Pareto, unfortunately, misunderstood and misinterpreted Walras's general equilibrium theory, especially, theory of money. They claim that Walras's theory is both incomplete and even wrong, or that the problem of money is not discussed by him at all [8]. Moreover, from the very beginning, Walras's money theory is simply ignored ${ }^{1}$.

Crucial attribute of Walras's money theory, which was completely misunderstood and was absolutely given up yields serious confusion, is the fact that Walras as well as Smith considered two types of money: money as a medium of exchange, a measure of value and store of value where the money commodity (numéraire) has to used; and money for circulating where either the money commodity (numéraire) or fiat money might be used. Thus, there are two different prices for the money commodity: a) when money commodity is used as a measure of value its price equal to one; b) when money commodity is used in circulating its price equal to the rate of interest.

In contrast, in the works of most post-Walras economists economic and financial sectors are separated and these authors have been claiming that money commodity (numéraire) is not money [9]. Therefore, it is not accidental that post-Walras's money theory is generally considered one type of money-fiat money: "We now live instead in a world of pure 'fiat' units of account, where the value of each depends solely upon the policies of the particular central bank with responsibility for it” ([10], p. 1; see also [11] [12]). Moreover in the modern general equilibrium theory, money either disappeared (Arrow-Debreu Model) (vide infra), or is considered in very simplified form and with unrealistic assumptions (see Applicable (Computable) General Equilibrium, Input-Output Analysis, and Dynamic Stochastic General Equilibrium Theory).

The paper consists of this introduction, three sections and a conclusion. The second section, The Relationship between Economic Theory and Reality, discussed the relationship between the economic theory and reality. Here, Walras's ten unknown assumptions are considered, which were rediscovered by post-Walras authors and has

${ }^{1}$ Recently published two books: The foundations of monetary economics [58], and Capital Theory [59], have totally ignored Walras's contributions. 
been using in proving of equilibrium existence. Yet, six unrealistic assumptions of the modern economic theory are discussed.

The third section, Using of Mathematics in Economic Theory, is divided into two parts: 1) the first part demonstrates Walras's achievement in the using of mathematics in his general equilibrium theory; the complete model for the individual's economy for the circulating and money economy is firstly presented; illustrates Walras's common method of equilibrium establishment and re-establishment, how the initial disequilibrium state is transformed into the equilibrium state by his famous algorithm—-tâtonnement. 2) The second part considers the Arrow-Debreu model as representative of the modern general equilibrium theory (MGET).

The fourth section, The Theory of Money, is also divided into two parts: 1) the first part discusses Walras's theory of money, its main characteristics and attributes, in both micro and macro levels; 2) the second part considers the modern theory of money: firstly, Clower's microfoundation of monetary theory is observed; secondly, the modern monetary theory is generally discussed.

\section{The Relationship between Economic Theory and Reality}

Following the classics (Smith, Ricardo, and Marx) Walras determined the method firstly to sciences in general and then specifically to economic science as:

... the pure theory of economies ought to take over from experience certain concepts, like those of exchange, supply, demand, market, capital, income, productive services and products. From these real-type concepts the pure science of economies should then abstract and define ideal-type concepts in terms of which it carries on its reasoning. The return to reality should not take place until the science is completed and then only with a view to practical application. Thus in an ideal market we have ideal prices which stand in an exact relation to an ideal demand and supply ([2], p. 71).

From this the following three statements are derived: first, there should be the reciprocal relationship between theory and reality; second, Abstract Theory means the simplification of real economics by means of assumptions; and third, the main task of such a theory should be its practical application ([2], p. 72; see also [13]).

As it was mentioned above the "abstract method" means that theory reproduces real economic life only in a "simpler" form, in such way that theory has not be contradict reality, moreover, it has to be guided by reality. It is clear that abstract theory could never reproduce reality exactly, but theory must be as close as possible to it ([14], p. 1).

For example, Walras assumed that his general equilibrium theory is characterized by free competition, uniform prices and public sector (taxation) and international trade are not included. But, in Walras's approach to the equilibrium state there might be voluntary unemployment of services (including labor) with strict positive price ${ }^{2}$. In the post-Walrasian approach (including the modern one), in such a case price is equal to zero, something that contradicts reality (vide infra). In this case, it is not "abstract method" but absurdity (vide infra).

Scientific approach is also characterized by evolutionary approach. The evolutionary approach means compatibility between progress of human society and economic theory. This means that paradigms must be replaced accordance with changes in economics, such that there has to be compatibility between them. This may be carried out by a step by step approach as Walras suggested considering four types of economy, according to the evolution of human society: the 1) exchange, 2) production, 3) capital formation and credit, and 4) circulation and money ([15], pp. 367-368) ${ }^{3}$. Each economy is characterized by its specific markets, but the markets of prior economy are included in the market system of the subsequent economy ([2], p. 40).

Yet, the laws of equilibrium establishment for any certain type of economy (low level) have to be included for the next types of economies (higher level) [16]. For example, the law of supply and demand established for an exchange economy - where it was assumed that there exist both demand and supply functions for all goods. Walras included this law for the following types of economy, where supply function for goods and demand functions for services are not used. However, in order to use this law, his model of general equilibrium included two system of equations: 1) a system of equations to obtain the supply price (cost of production) for a good to compare this to its corresponding selling (demand) price, as determined from its demand curves; and 2) a system

\footnotetext{
${ }^{2}$ In Walras's scheme of the subject, pure economics dealt with the abstract analysis of a fully competitive economy, a hypothetical but broadly realistic model' ([60], p. 210).

${ }^{3}$ Therefore, we cannot agree with Van Daal which claims that this approach was intended by Walras “as pedagogical devices” ([15], pp. xxvii-xxix).
} 
of equations to obtain demand (required) quantities of services, to compare with its corresponding supply quantities as determined from its supply curves (for how this works, see below).

\subsection{Walras's Assumptions and Definitions}

Let us now to consider Walras's assumptions and definitions. First, two well-known assumptions would be discussed: free (not perfect!) competition and uniform prices. In the market with free competition, the internal forces of market establish equilibrium prices, which are guarantied by free movement for each individual, in and out of the market, according to his own wishes only. This means that each individual participates in the establishment of equilibrium prices and might influence their magnitude. Therefore, each individual in the market with free competition is much more "price maker" than "price taker", which is opposite to the claiming of the modern authors that in Walras's economy is "price taker". Yet, Walras's economy is a decentralized economy, where individuals organize their economic life. This is contrary to the statement of some modern economists who claim that Walras's economy is a centralized economy.

Second, well-known assumption, uniform prices-price of each good and service is the same for all consumers and entrepreneurs-is generally consistent to the market with free competition.

Walras also assumed, fortunately, a number of assumptions in his Elements, except above mentioned wellknown assumptions: free competition and uniform prices, which until today have been ignoring by post-Walras's economists, however these assumptions enable to achieve at equilibrium state where might be voluntary unemployment with strictly positive prices. It must be emphasized that majority of Walras's assumptions have been rediscovering by the modern authors and have been using in the proving of equilibrium existence.

There are the relevant assumptions and definitions in Walras's general equilibrium theory:

1) Strictly decreasing or strictly increasing curves (functions) ([2], p. 466 and p. 467])

2) Continuity or discontinuity of curves (functions)

Demand and supply curves for an individual may be either continuous or discontinuous while total demand and supply curves should be continuous ([2], p. 95].

3) Effective offer and effective demand

Walras determined the effective offer ([2], p. 84) and the effective demand ([2], p. 85) as, for a particular quantity, there is only one price, and vice versa that is consistence with two previous assumptions.

4) Condition for partial equilibrium state (effective offer = effective demand) ([2], p. 85)

5) Boundary of demand and offer

The demand and the offer curves are bounded by an available quantity from above for both the individual and total economies ([2], p. 116; p. 166; p. 171).

6) Positiveness of prices

Prices, both goods for consumption and services are strictly positive ([2], p. 170 and p. 249).

7) Primary (original) and derived (general) functional relations

Walras considered two types of functional relations between price and quantity for both demand and offer. The first was the primary (original) functional relation. This means that the quantity of a certain commodity depends only on its price and conversely the price of a certain commodity depends only on its quantity. In other words, there is a reversible relationship between quantity and price for a certain commodity separately. Walras's second functional relationship is the derived (general) relationship. In this case the quantity (demand or supply) of any commodity depends on the prices of all commodities and services. Here the principle of reversibility does not hold. A derived functional relation is a result of the solution of the model for each individual's economy for any given prices system (vide infra).

8) Standard measure of utility ([2], p. 117)

9) Direct and indirect utility

Walras considered two types of utility. The first, direct utility, which is the utility of a certain commodity or services consumed by an individual and they are appearing in the utility function. The second type of utility is the indirect utility of certain commodities which are not consumed directly by individuals, but are required during either the consumption or production process; and therefore, they are not appearing in the utility function.

10) Data

According to Walras's approach, each individual schedules his demand for and supply of goods and services ([2], p. 93). Yet, the data are not change during the process of equilibrium establishment on the first phase of the 
establishment of equilibrium ([2], p. 242); and then changing of the data the re-establishment of equilibrium might be required on the second phase of the establishment of equilibrium.

\subsection{Unrealistic Assumptions of the Modern Economic Theory}

Instead of gradually replaced some Walrasian outdated assumptions by assumptions that are compatible with contemporary economics such as mixed (free and imperfect) competition, price discrimination and international trade and taxation (public sector), modern general equilibrium theory has been rediscovering and using almost all of Walras's assumptions; moreover, also introduced an additional unrealistic assumptions that makes modern economic theory incompatible to reality. Post-Walras's economists ignoring Walras's unknown assumptions and have been blaming him as if the problem of equilibrium existence, uniqueness and stability and comparativestatic was not discussed him at all. Therefore, the main task of them since 30th was the rigorous proof of equilibrium existence. However, this proof was based on unrealistic assumptions, and therefore, in the way of proofing the economics was lost.

The following unrealistic assumptions are used in the modern economic theory:

1) Price of several goods and services might be equal to zero and even might be negative.

Post-Walras authors misunderstood Walras's method of equilibrium establishment, namely, that Walras used two macro model (equilibrium and disequilibrium) and demonstrated how disequilibrium model is transformed into equilibrium model by iterative process (tâtonnement), blamed him as if he considered only equilibrium model, characterized by equations system with equality [28]-[30]. Therefore, they substituted the effective supply of factors by their available quantities and the cost of production by the given selling prices of commodities in the Walras's equations of quantities of services and of prices of commodities, respectively. Then, the demand quantities for services by sectors of production and prices of services are became unknowns. The results of the solution of such equations system by the tools of mathematics are that some prices of services might be zero and even negative [23]. Some economists accepted that prices might be zero but disagreed that the price might be negative. Therefore, in order to eliminate such possibilities the equality was replaced by inequality. Unfortunately, this replacement caused another difficulty, and it yields the following unrealistic assumption.

2) Free good conception (non-classical).

This assumption says us that when there is an excess supply of a service (a product), i.e., an unused part of the service (the good) it is called "free good" (mockery to the Classical free goods conception) and its price equals zero. In other words, in equilibrium, if a certain service is not fully employed, then its price is zero. For example, if unemployment exists, then wages should be equal to zero [16] [17]. But in this case, such a theory contradicts reality (vide infra).

3) All economic agents (consumers and producers) are concentrated in one whole model.

This type of model, when all economical agents are included (comprised) in one model, differs from Walras's model where each economic agent (consumers and producers) solves his economic problems individually (separately) depending only on his personal goals (maximum utility, or maximum profits, and so on) by micro model; afterward, the adjustment between these individual solutions occurs by the macro model. In other words the process is divided into two stages: individual activities and the adjustment between them, i.e., establishment of equilibrium. It must be stressing that this approach is based on real economics and therefore, there is a natural integration between microeconomics and macroeconomics. In the case when all agents included in one model, the solution of individuals' economic problems and their adjustment (equilibrium establishment) has simultaneously occurred. This approach has two problematic issues: firstly, since models of all individuals are solved together, it is natural that an interpersonal comparison of their goals (utilities) occurs; secondly, and most important, such model has huge dimensions, which makes impossible its practical realization (solution) even by means of the modern superpower computer.

4) The excess demand (supply) for goods and services is determined as a difference between the final endowment and the initial (available) endowment.

Such determination of the excess demand (supply) has some negative consequences from the point of economics. First, the demand and supply are not directly determined; therefore there is illusion that as if the whole available quantity of commodities and services are traded. Consequently, second, it is not clear what part of commodities and services is actually traded and what part is not traded, that is, what part is unemployed (unsold). Finally, despite of that the excess demand is sometimes determined as a function of prices the original linkage 
between prices and quantities is destroyed (vide infra).

5) There is only one type of money-fiat money.

From the seventies, the majority of countries of the world used a fiat money as standard money; fiat money replaced the money commodity and had to fulfill all four functions of money. But this is opposite with the principal statement of classical money theory, that only money commodity have to serve as a measure of value, and fiat money has to be only used in circulation. Moreover, the quantity of fiat money must be regularized by the quantity of the money commodity [18] [19].

The replacement of the money commodity by the fiat money has yielded several undesirable phenomena, predecessors of the financial bubbles. First, because the fiat money has no objective value ${ }^{4}$, economics is managed without valuating of goods and services. Second, because there is only one type of money, namely fiat money, there is only one price - the rate of interest and the price of the money commodity is absent. Therefore, this is another reason why fiat money cannot be served as a measure of value. Third, there are no obstacles and no limit to printing paper money [17]-[19].

6) The demand function for money is an inverse function to the income function.

Modern monetary theory is essentially based on the money theory of Keynes; however, the latter is incomplete and even incorrect. For example, Keynes asserted that the liquidity function of the amount of cash depends mainly on the income. By means of this, Keynes assumed that the liquidity function is the inverse function of the income function. However, the inverse function exist only for the function of one variable with specific properties, namely, the function must be either strictly increasing or strictly decreasing function. But, the income function is the function for many variables (prices and available quantities for all categories-goods, factors of production (labour, fixed capital and money) and so on). Therefore, the assumption that the income function as the function of one variable, ones of money, ones of available quantities of either labour or fixed capital, is incorrect [19].

The modern economic theory, based even if on one of above mentioned unrealistic assumptions, is incompatible with reality; hence its applicability is doubtful, though from the point of view of used mathematics it might be indeed remarkable achievement. In practice, several unrealistic assumptions are simultaneously used by the modern economic theory for the serious issues.

\section{Using of Mathematics in Economic Theory}

Walras stated that a successful realization of his program of general equilibrium theory could be only implemented by means of using mathematics throughout all three parts, especially for pure theory ([2], p. 43; see also p. 72). At the same time, Walras understood the difficulties of using mathematics in economic theory and additional difficulties that involved overcoming his colleagues’ obstacles ([2], pp. 47-48).

Hence, it is not accidental that modern authors have tried to persuade us that current economics "became" mathematical science [73] [74]. Supposedly, these claims are based on the well-known law of the dialectics whereby quantitative changes become qualitative changes. For this to happen, these works must research economic problems, which, unfortunately, are not the case [1].

To make their argument more convincing the modern authors have been trying to delegitimate Walras's mathematics claiming that it is primitive, clumsy, dubious, and even incorrect. Almost every author who has written about Walras and his economics has felt obliged to emphasize this fact ([20], p. 1; [15], p. xxxi).

Even Jaffé capitulated to the common attack on Walras's mathematics, and, unfortunately, joined Walras's critics ([21], p. 347; [2], p. 5).

To sum up, the following main claims have been made against Walras's mathematics in post-Walras mathematical economic literature:

1) Walras's general equilibrium theory has only contained equalities ${ }^{5}$;

2) Walras did not discuss existence of equilibrium and reduced existing problems to the equality of the numbers, of variables and independent equations of the model ${ }^{6}$.

3) Walras did not consider the problem of comparative static ([22], p. 61).

\footnotetext{
${ }^{4}$ Magill, M. and M. Quinzii ([11], p. 304) write "our money is fiat money and not deposit money" [12].

${ }^{5}$ Walras thought that the existence question is answered as soon as we have counted equations and unknowns, and found that they are equal in number' ([61], p. 106).

${ }^{6}$ Van Daal ([15], xxviii) writes: "He considered it as guaranteed by the equality of the numbers of variables and independent equations of the model” (see also [62], p. 4; [63], p. 284].
} 
4) Walras's tâtonnement is clumsy and primitive ([3], p. 4); [23].

5) Walras's model is only characterized by the market clearing principle where the total offer is equal to its total available quantity [22].

6) Walras's general equilibrium theory does not know "Walras' Law” ([24], p. 40).

7) Walras's tâtonnement is the process of adjustment only of prices without of quantities ([25], p. 4; [26], p. 99).

In order to verify whether these claims are true or false let us describe Walras's original models: micro and macro economics by presenting them in the modern mathematical terms.

Finally, I would like to emphasize that models, micro and macro, in this paper are only "the translation" of Walras's original models into the modern mathematical language.

\subsection{Walras's Model of Individual's Economy in Circulation and Money}

The economy of individuals is essential in Walras's general equilibrium theory. The process of equilibrium establishment is started by the solution of a mathematical model for each individual allowing him/her to obtain the demand and supply for goods and services (including money). First, the mathematical model is uniform for all kinds of agents' economy ${ }^{7}$. Second, the model of individual's economy illustrates Walras's evolutionary approach. Unfortunately, when Walras's approach is discussed in the post-Walrasian literature, the model of individual's economy is presented either through the exchange economy (in general), or through the production economy $^{8}$. Moreover, this representation of Walras's model differs from his original model and is incomplete (vide infra).

It must be pointed out that after production economy Walras discussed only new additional markets, characteristic of discussing economy, assuming that markets of previous economies (Exchange and Production) are included in both micro and macro models. Therefore, to my best knowledge, neither Walras nor post-Walras authors have presented the complete model of individual's economy for Circulation and Money. Conversely, the model of the whole (macro) economy was completely presented (only for equilibrium state) by Jolink and van Daal ([27], pp. 151-158).

Now, Walras's original and complete model for each individual's economy in the Circulation and Money economy might be formulated as:

$$
\begin{gathered}
\text { Maximize } \sum_{i=1}^{m} \Phi_{i}\left(x_{i}\right)+\sum_{j_{1}=1}^{t} \Phi_{j_{1}}^{t}\left(y_{j_{1}}^{t}\right)+\sum_{j_{2}=1}^{p} \Phi_{j_{2}}^{p}\left(y_{j_{2}}^{p}\right)+\sum_{j_{3}=1}^{l} \Phi_{j_{3}}^{k}\left(y_{j_{3}}^{k}\right)+\Phi_{e}\left(x_{e}\right) \\
+\sum_{i^{\prime}=1}^{m} \Phi_{i^{\prime}}\left(x_{i^{\prime}}\right)+\sum_{i^{\prime \prime}=1}^{m} \Phi_{i^{\prime \prime}}\left(x_{i^{\prime \prime}}\right)+\Phi_{e^{\prime}}\left(x_{e^{\prime}}\right)
\end{gathered}
$$

subject to

$$
\begin{gathered}
y_{j_{1}}^{t}-d_{j_{1}}^{t}+o_{j_{1}}^{t}=q_{j_{1}}^{t}, \quad\left(j_{1}=1,2, \cdots, t\right), \\
y_{j_{2}}^{p}-d_{j_{2}}^{p}+o_{j_{2}}^{p}=q_{j_{2}}^{p}, \quad\left(j_{2}=1,2, \cdots, p\right), \\
y_{j_{3}}^{k}-d_{j_{3}}^{k}+o_{j_{3}}^{k}=q_{j_{3}}^{k}, \quad\left(j_{3}=1,2, \cdots, l\right), \\
x_{e}-d_{e}+o_{e}=q_{e}, \\
x_{i^{\prime}}-d_{i^{\prime}}+o_{i^{\prime}}=q_{i^{\prime}}, \quad\left(i^{\prime}=1,2, \cdots, m\right), \\
o_{u} p_{u^{\prime}}=q_{u} p_{u^{\prime}}-\sum_{i^{\prime}=1}^{m} x_{i^{\prime}} p_{i^{\prime}}-X_{e^{\prime}} p_{e^{\prime}} \\
x_{1}+\sum_{i=2}^{m} x_{i} p_{i}-\sum_{j_{1}=1}^{t} o_{j_{1}}^{t} p_{j_{1}}^{t}+\sum_{j_{1}=1}^{t} d_{j_{1}}^{t} p_{j_{1}}^{t}-\sum_{j_{2}=1}^{p} o_{j_{2}}^{p} p_{j_{2}}^{p}+\sum_{j_{2}=1}^{p} d_{j_{2}}^{p} p_{j_{2}}^{p} \\
-\sum_{j_{3}=1}^{l} o_{j_{3}}^{k} p_{j_{3}}^{k}+\sum_{j_{3}=1}^{l} d_{j_{3}}^{k} p_{j_{3}}^{k}-o_{e} p_{e}+d_{e} p_{e}-\sum_{i=1}^{m} o_{i^{\prime}} p_{i^{\prime}}+\sum_{i=1}^{m} d_{i^{\prime}} p_{i^{\prime}} \\
+\sum_{i^{\prime}=1}^{m} x_{i^{\prime}} p_{i^{\prime \prime}}-q_{u} p_{u^{\prime}}-\sum_{s=1}^{S} q_{s}^{m} p_{s}^{m}+x_{e^{\prime}} p_{e^{\prime}}=0 \\
x_{1}, x_{i}, y_{j}, x_{e}, d_{j}, o_{j}, x_{i^{\prime}}, x_{i^{\prime}}, o_{i^{\prime}}, d_{i^{\prime}}, d_{e}, o_{e} \text { and } o_{u} \geq 0,\left(i=2,3, \cdots, m ; j\left(j_{1}+j_{2}+j_{3}\right)=1,2, \cdots, n(t+p+l)\right),
\end{gathered}
$$

7"In the economic literature the difference between the production units (firms) and consumption units (households) is very relative” ([64], p 4).

8“"What cutes know about Walras amounts to the following caricature. Walras developed the general economic equilibrium model, but did not care about uniqueness and stability of an equilibrium" [65]. 
where

$\Phi_{i}\left(x_{i}\right), \Phi_{j}\left(y_{j}\right), \Phi_{e}\left(x_{e}\right), \Phi_{i^{\prime}}\left(x_{i^{\prime}}\right), \Phi_{i^{\prime \prime}}\left(x_{i^{\prime \prime}}\right), \Phi_{e^{\prime}}\left(x_{e^{\prime}}\right)$-utility functions for product, for services, for net income, for circulating capital goods, for circulating capital goods and net income in monetary terms respectively;

$q_{j}, q_{i^{\prime}}, q_{e}, q_{u}$-is the available quantities of services, of circulating capital goods, of net income and of money respectively;

$p_{i}, p_{j}, p_{e}, p_{i^{\prime}}, p_{i^{\prime \prime}}, p_{u}, p_{u^{\prime}}, p_{e^{\prime}}$-is the price of product, of services, of net income, of circulating capital goods, of circulating capital goods in monetary terms, price of numeraire, price of money, and price of net income in monetary commodity terms, respectively;

$x_{i}, x_{i^{\prime \prime}}, x_{e^{\prime}}$-is the demand quantity for product $i$, for circulating capital goods in monetary terms, and for net income in monetary terms, respectively;

$d_{j}, o_{j}, d_{i^{\prime}}, o_{i^{\prime}}, d_{e}, o_{e}, o_{u}$ - is the demand or offer of services $j$; or the demand or offer of the circulating capital goods; or the demand or offer of net income; and the offer of money, respectively;

$y_{j}, x_{i^{\prime}}, x_{e}$-is the quantity of services which finally remains at the individual's disposal as a result of exchange and it is equal either to $\left(q_{j}+d_{j}\right)$ or $\left(q_{j}-o_{j}\right)$; or it is the quantity of circulating capital goods which finally remain with the individual as a result of exchange; it is equal either to $\left(q_{i^{\prime}}+d_{i^{\prime}}\right)$ or $\left(=q_{i^{\prime}}-o_{i^{\prime}}\right)$; or it is the quantity of net income which finally remains with the individual as the result of exchange, and it is equal to ( $q_{e}$ $\left.+d_{e}\right)$ or $\left(q_{e}+o_{e}\right)$;

- conditions (3.1-2)-(3.1-4) indicate that an offer of a certain service cannot exceed its available quantity;

- condition (3.1-5) indicates that an offer of a net income cannot exceed its available quantity;

- conditions (3.1-6) indicate that an offer of certain circulating capital goods cannot exceed its available quantity;

- condition (3.1-7) indicates that an offer of a money for circulation cannot exceed its available quantity;

- condition (3.1-8) is a budget constraint for individual, which means that the demand for product used as the numéraire depends on the balance between the value of demand (expenditure) for products not used as the numéraire $\left(\sum_{i=2}^{m} x_{i} p_{i}\right)$, the demand for services $\left(\sum_{j=1}^{n} d_{j} p_{j}\right)$, the demand for net income $\left(d_{e} p_{e}\right)$ and the demand for circulating capital goods $\left(\sum_{i=1}^{m} d_{i^{\prime}} p_{i^{\prime}}\right)$, i.e.

$$
d=\left(\sum_{i=2}^{m} x_{i} p_{i}+\sum_{j_{1}=1}^{t} d_{j_{1}}^{t} p_{j_{1}}^{t}+\sum_{j_{2}=1}^{p} d_{j_{2}}^{p} p_{j_{2}}^{p}+\sum_{j_{3}=1}^{l} d_{j_{3}}^{k} p_{j_{3}}^{k}+d_{e} p_{e}+\sum_{i=1}^{m} d_{i^{\prime}} p_{i^{\prime}}\right),
$$

and the value of offer (income) of services $\left(\sum_{j=1}^{n} o_{j} p_{j}\right)$, offer of net income $\left(o_{e} p_{e}\right)$, offer of circulating capital goods $\left(\sum_{i=1}^{m} o_{i^{\prime}} p_{i^{\prime}}\right)$, offer of money for circulation $\left(o_{u} p_{u^{\prime}}\right)$, offer of raw materials $\left(\Sigma_{s=1}^{S} q_{s}^{m} p_{s}^{m}\right)$, i.e.,

$$
o=\left(\sum_{j_{1}=1}^{t} o_{j_{1}}^{t} p_{j_{1}}^{t}+\sum_{j_{2}=1}^{p} o_{j_{2}}^{p} p_{j_{2}}^{p}+\sum_{j_{3}=1}^{l} o_{j_{3}}^{k} p_{j_{3}}^{k}+o_{e} p_{e}+\sum_{i=1}^{m} o_{i^{\prime}} p_{i^{\prime}}+o_{u} p_{u^{\prime}}+\sum_{s=1}^{S} q_{s}^{m} p_{s}^{m}\right),
$$

and

$$
d_{1}=(o-d) .
$$

This model is characterized by some special attributes:

a) for each service (goods) either the demand for or the offer of is obtained;

b) the offer is limited by the available quantity; i.e., the offer might be less or equal to available quantity;

c) the demand for the money commodity is equal to the income minus the expenditure;

d) the demand for all goods (or services) is limited by the budget constraint;

e) The derived demand (supply) function for all categories (products, services and so on) for the Circulation and Money economy, is obtained as a result of the individual model solution that includes all the following parameters: the prices of products $\left(p_{i}\right)$ and the parameter of their utility function $\left(\phi_{i}\right)$; the available quantity of services $\left(q_{j}\right)$, their prices $\left(p_{j}\right)$, and the parameter of their utility function $\left(\phi_{j}\right)$; the price of a new income $\left(p_{e}\right)$ and the parameter of its utility function $\left(\phi_{e}\right)$; the available quantity of circulating products $\left(q_{i^{\prime}}\right)$, their prices $\left(p_{i^{\prime}}\right)$, and the parameter of their utility function $\left(\phi_{i^{\prime}}\right)$; the available quantities of raw materials $\left(q_{s}^{m}\right)$ and their prices $\left(p_{s}^{m}\right)$; the available quantity of money for circulation $\left(q_{u}\right)$, its price $\left(p_{u^{\prime}}\right)$ and the utility functions' parameters of circulating products in monetary terms $\left(\phi_{i^{\prime \prime}}\right)$ including commodity an income $(E)$. This is:

$$
\begin{aligned}
& d=f\left(p_{2}, p_{3}, \cdots, p_{m} ; p_{1}^{t}, p_{2}^{t}, \cdots, p_{t}^{t} ; p_{1}^{p}, p_{2}^{p}, \cdots, p_{p}^{p} ; p_{1}^{k}, p_{2}^{k}, \cdots, p_{l}^{k} ; p_{e} ; p_{1^{\prime}}, p_{2^{\prime}}, \cdots, p_{m^{\prime}} ;\right. \\
& p_{1^{\prime}}^{m}, p_{2^{\prime}}^{m}, \cdots, p_{s^{\prime}}^{m} ; p_{u^{\prime}} ; q_{1}^{t}, q_{2}^{t}, \cdots, q_{t}^{t} ; q_{1}^{p}, q_{2}^{p}, \cdots, q_{p}^{p} ; q_{1}^{k}, q_{2}^{k}, \cdots, q_{l}^{k} ; q_{e} ; q_{1^{\prime}}, q_{2^{\prime}}, \cdots, q_{m^{\prime}} ; \\
& \left.q_{1^{\prime}}^{m}, q_{2^{\prime}}^{m}, \cdots, q_{s^{\prime}}^{m} ; q_{u} ; \phi_{1}, \cdots, \phi_{m} ; \phi_{1}^{t}, \cdots, \phi_{t}^{t} ; \phi_{1}^{p}, \cdots, \phi_{p}^{p} ; \phi_{1}^{k}, \cdots, \phi_{l}^{k} ; \phi_{1^{\prime}}, \cdots, \phi_{m^{\prime}} ; \phi_{1^{\prime \prime}}, \cdots, \phi_{m^{\prime \prime}} ; \phi_{e} ; \phi_{e^{\prime}}\right) ;
\end{aligned}
$$


For simplicity, $d$ is used to express a common notation for demand and supply functions for all kinds of commodities and services;

( $f$ ) The condition—guarantees maximum satisfaction for each individual in this model—-the marginal utility of a certain good (service) is equal to marginal utility of the money commodity (numeraire) multiplied by the price of the good (service) in question. This condition is identical to the way Walras formulated it ([2], p. 164)

$$
\phi_{i}\left(x_{i}\right)=p_{i} \phi_{1}\left(x_{1}\right), \quad(i=1,2, \cdots, m)
$$

where $\phi_{i}\left(x_{i}\right)$ is marginal utility of good $i, \phi_{1}\left(x_{1}\right)$ is a marginal utility of the money commodity, and $p_{i}$ is the price of good $i$.

It has to be emphasized that Walras's originally derived demand (supply) function, both generally and for Circulation and Money, seems to be incomplete; it differs from the above function because it includes only all prices

$$
\begin{gathered}
d=f\left(p_{2}, p_{3}, \cdots, p_{m} ; p_{1}^{t}, p_{2}^{t}, \cdots, p_{t}^{t} ; p_{1}^{p}, p_{2}^{p}, \cdots, p_{p}^{p} ; p_{1}^{k}, p_{2}^{k}, \cdots, p_{l}^{k} ;\right. \\
\left.p_{e} ; p_{1^{\prime}}, p_{2^{\prime}}, \cdots, p_{m^{\prime}} ; p_{1^{\prime}}^{m}, p_{2^{\prime}}^{m}, \cdots, p_{s^{\prime}}^{m} ; p_{u^{\prime}}\right) ;
\end{gathered}
$$

However, if we take into account Walras's method of equilibrium establishment this difference is misleading. The parameters of Walras's individual model might be divided into two types: first, the internal parameters, i.e. the initial available quantities and the utility functions of goods (services), and, secondly, the external parameters, i.e., their prices, which from the point of macro economy are unknown. However, it must be pointed out that the prices become known for each iteration of the adjustment process (tâtonnement). Consequently, Walras divided the process of equilibrium establishment into two stages. The first stage of the process is the establishment of the equilibrium prices (external parameters) for the given available quantities and utility function (internal parameters). The second stage of the process is the analysis of the variation of prices (equilibrium re-establishment) when initial quantities and utility functions are changed. Thus, Walras's definition of derived (general) demand (supply) functions relates to the first stage. This means that the demand (or offer) of a certain commodity depends only on the prices of all commodities until general equilibrium is established. When equilibrium is established during the second stage of the process, the demand and supply is also dependant on the internal parameters - the available quantity and parameters of utility functions. So, Walras's derived demand (offer) function is consistent with the modern mathematical programming.

Walras's followers have misunderstood his two stage approach since Pareto [3] [23] [28]-[33]. They altered the first stage and although the second stage was realized, this realization differed from Walras's approach ([34], pp. 96-97). It is important to note two things. First, Samuelson considers only two parameters (prices and income) while the third parameter of utility functions is missing. Second, Samuelson assumes that the original demand function might be identified with the derived demand function and that it is acceptable for each individual. Samuelson's determination of the derived demand function was borrowed by the modern authors and named it "Walrasian demand function" ([35], p. 51)

Moreover, post-Walras's authors have been claiming that Walras did not discuss problems of comparative static in his general equilibrium theory $([22] \text {, p. } 61 \text {; [36] })^{10}$.

The aggregation of results for all individuals' model allows to determine the total quantities of demand $\left(D_{i}\right)$ for every product; the total offer $\left(O_{j}\right)$ of every services for the production, which are obtained as the difference between total offer and total demand for all individuals' consumption; the total demand of income for savings $(E)$; the total offer of every circulating capital goods' services $\left(O_{i}\right)$; the total offer of money $\left(O_{u}\right)$ for circulation, which is obtained as the difference between total offer (available quantity) and total demand for individuals, which would be used in the macro model for the equilibrium establishment.

\subsection{Walras's Macroeconomic Model for Circulation and Money Economy}

If the equilibrium exists in the framework of the initially given data, in order to realize iterative process

\footnotetext{
9“This demand function has also been called the Marshallian demand function. However, this terminology can create confusion, and so we do not use it here" ([35], p. 51).

10“'It was an achievement of the first magnitude for the older mathematical economists to have shown that the number of independent and consistent economic relations was in a wide variety of case sufficient to determine the equilibrium values of unknown economic prices and quantities” ([34], p. 257].
} 
(tâtonnement) and establish the equilibrium state in addition to the results from "the models of individuals" economy (vide supra) the following variables are required: the total demand for services and their offer prices, products' cost of production, the total demand quantities of new capital goods and their supply prices (cost of production), the total demand quantities of circulation capital goods, of money and of raw materials. This paper considers only the macro model with fiat money for circulating because using of the money commodity does not influence the results (see Appendix I).

To sum up, there are $5 m+2 n+3 S+2 l+4$ independent equations to determine $5 m+2 n+3 S+2 l+4$ unknowns that guarantee the solution as Walras stated. Indeed, Walras finished the process of equilibrium establishment for each economy stating that the number of independent equations equals to the number of unknowns in equilibrium state. For example, for the production economy he stated "At all events, in a state of equilibrium, there will remain $2 m+2 n-1$ equations to determine $2 m+2 n-1$ unknowns” ([2], p. 241). Moreover, Walras specifically emphasized this in the Preface for the 4th edition of Elements: "I feel constrained to have always as many equations as there are unknowns in my problems” ([2], p. 47]. So, it seems that the authors, who have been claiming that Walras's proof of equilibrium existence is reduced to the equality between the number of indipendent equations and the number of unknowns, are correct.

However, careful analysis of the mentioned above Walras's determination of statement draws another picture. There are two key words in Walras's determination of the statment. First, "in equilibrium state", this means that, Walras always emphasized that this statement is only correct in the equilibrium state because, in equilibrium state, where (demand = supply) and (cost of production = selling price), two unknowns might be reduced to one. So, in equilibrium state the number of unknowns is halfed. Second, by "feel constrained" Walras means that the equilibrium state is obtained by the transformation of disequilibrium state, where (demand $\neq$ supply) and (cost of production $\neq$ selling price), into equilibrium state. So, in disequilibrium state the number of unknowns is greater than the number of indipendent equations. In such a case to start equilibrium establishing process (solution) it is necessary to give the excess number of unknowns. Therefore, Walras started the solution process for each economy by assumption that the excessive number of unknowns is given ([2], Lesson 21, p. 243; see also Lesson [12], p. 169; Lesson 25, p. 284; Lesson 30, p. 325); for the Exchange, Capital and credit, and Circulation and Money economies respectively].

The presentation of macro model (3.2-1)-(3.2-15) demonstrates the above discussion. So, actually there are additional $n+2 m+2 l+2 S+2$ unknowns according to the equation systems (3.2-6)-(3.2-14). In equilibrium state, as in this model, the equalities and these unknowns might be eliminated. However, in the beginning of the equilibrium establishment process, for any random price system there might be inequality and therefore, these unknowns do not eliminate and therefore, in the equation systems (3.2-6)-(3.2-15) instead of equalities would be inequalities (see Appendix II). Therefore, the process (tâtonnement) of equilibrium establishment is required.

In conclusion, Walras's statement, according to which the number of independent equations is equal to the number of unknowns in equilibrium state, is conceived after the equilibrium is established by iterative process (tâtonnement), when the disequilibrium state is transformed in the equilibrium state; therefore, it is a necessary and satisfactory condition for equilibrium existence. However, since post-Walras's authors used this statement to establish equilibrium (solving the problem), it has become a neccessity, but not a satisfactory condition for equilibrium existence.

\subsection{Modern General Equilibrium Theory}

In this section, we discuss the Arrow-Debreu model as representative of the modern GET. It is clear that over the last 40 years certain improvements in it have been made, such as the addition of taxation and inter-country trading problems. But the theoretical basis of computable GET is still the Arrow-Debreu GE model [3] [37].

Arrow-Debreu's basic GE model might be described as follows ([3], p. 107).

The Arrow-Debreu model is closer to Pareto's version of GE than Walras. This follows from the fact that the problem of the establishment of equilibrium is solved in one stage. In other words, all consumers and all producers are concentrated in one model. However, if there is a strong theoretical solution to the Arrow-Debreu model, it is impossible to realize practically even for a small country, as Pareto frankly confessed. In addition, in the Arrow-Debreu case, the adjustment process between supply and demand is superfluous. Another difference is that prices are obtained by the model's solution directly, and not determined by means of the given framework of demand function for goods and supply functions of services. Hence, prices might reach any magnitude, and 
some prices might be zero. Therefore, prices in the Arrow-Debreu model do not have any connection to current prices $^{11}$. A final difference is that the utility function for each household is described as a function of all goods and all services in one function simultaneously which is practically unrealizable. On the other hand there are two additional (positive) properties of the Arrow-Debreu model: firstly, the maximization of profits for each firm, and secondly, the distribution of the profits between households that have a share in the firm. However, they become useless because in the Arrow-Debreu approach prices of some gods and services might be zero (vide infra).

At the same time the Arrow-Debreu approach differs from Pareto's approach in one central condition of equilibrium. Namely, Pareto, as well as Walras, stated that for the equilibrium situation it is necessary that the selling prices of goods must equal to its cost of production (supply price). This means that in Pareto's approach, as well as Walras's, conditions of equilibrium are different for goods and for services. This condition in the Arrow-Debreu approach cannot be kept, because the cost of the production of goods is directly not determined; because of this it is important that not only the price of some goods might be equal to zero, but also the price of some services might be zero.

The main achievement of modern GET is the proof of equilibrium's existence "The proof of general equilibrium is the crowning achievement of mathematical economics” ([38], p. 440; [39]). It might be that the proof of its existence is a mathematical achievement, but the question is whether this proof is harmonious with the economic situation in reality. Therefore, let us discuss the proof of equilibrium existence from the point of view of economics.

For this purpose we shall now discuss the main assumptions of the modern GET.

Assumption $1(\mathrm{~F})$. To any $\mathbf{p}$ there corresponds a unique number $z_{i}(\mathbf{p})$ called the excess-demand function for $i$ and so a unique vector of excess-demand functions $\mathbf{z}(\mathbf{p})$. We have $z_{i}(\mathbf{p})=x_{i}(\mathbf{p})-y_{i}(\mathbf{p})-\bar{x}_{i}$ and call $x_{i}(\mathbf{p})$ the demand function and $y_{i}(\mathbf{p})$ the supply function ([3], p. 18).

This is very crucial assumption since the following assumptions and the whole process are based on this assumption since Pareto [40]. Firstly, the excess-demand function is used instead of demand and supply separately. The excess-demand function is determined by a comparison between the demand function and the supply function plus the available quantity of the good. Secondly, the available quantity is not presented as a function of price similarly to the demand and supply functions. Such a presentation of available quantity means that trade in it does not depend on price. In other words, this means that the available quantity is completely traded for any price. Such an approach is based on the implicit assumption that the part of the available quantity that is not traded is retained for the use of its owner and is considered as if it was traded. This implicit assumption creates the illusion that the available quantity is completely traded. Such approach prevents to determine unsold products for the exchange economy, and unemployment services for production, capital formation and money economies.

Yet, trading of the available quantity depends on price as well as the quantity produced. So, excess-demand $z_{i}(\mathbf{p})$ for $i$ must be determined as $z_{i}(\mathbf{p})=x_{i}(\mathbf{p})-y_{i}(\mathbf{p})-\bar{x}_{i}(\mathbf{p})$, where $\bar{x}_{i}(\mathbf{p}) \leq \bar{x}_{i}$. This means that presenting the supply side via two separate components, a newly produced quantity depending on price and the available quantity that does not depend on price, is incorrect.

Finally and this is very significant, according to Walras's approach for the production [1], capital formation [16] and money economies, the demand function for services and the supply functions for produced goods do not used. This means that the excess-demand functions cannot be beforehand determined at all for these economies.

Despite the latter conclusion, let us still assume that there is a possibility to obtain excess-demand functions in such economies. This gives us a possibility to discuss the other assumptions.

Assumption $2(\mathrm{H}) . \mathbf{z}(\mathbf{p})=\mathbf{z}(k \mathbf{p})$ for all $\mathbf{p}>\mathbf{0}$ and $k>0$; the excess-demand functions are homogeneous of degree zero in p. ([3], p. 19).

It is very difficult to understand this assumption from an economic perspective. First, homogeneous function is "very special case" ([41], p. 315). Second, the excess-demand function is the difference between the demand

\footnotetext{
${ }^{11}$ Moreover, recently Thijs ten Raa stated that shadow prices (Lagrange multipliers) have been using as a prices even for practical applications of input-output analysis: "If the quantity relations of input-output analysis are used to constrain the efficiency problem of an open economy, the associated Lagrange multipliers constitute a competitive price system and, by duality theorem of linear programming, they fulfill the value relations of input-output analysis. The phenomenon of complementary slackness and corollary to Carathéodory's theorem identify the comparative advantage of the economy” ([66], p. 15). Such statements mean a regression of economic science at least on fifty years.
} 
and the supply; therefore, this assumption might be applicable in one case only, namely, when the demand function and the supply function have a similar characteristic. In general, however, the demand curve is a decreasing function and the supply curve is an increasing function. Third, in Walras's money economy prices (cost of production) of goods are determined by means of services' prices and the rate of interest, which depends on the available quantity of money for circulation. This means that prices of goods and prices of services are differently changed. Hence, in an economy where saving, investment and money play a leading role, as distinguished from the Arrow-Debreu approach, this assumption might be irrelevant (problematic). Of course, it is much more problematic to use normalized prices ([3], pp. 19-20).

So, one unrealistic assumption is replaced for the other unrealistic assumption by the normalization of prices, because the normalization of prices eliminates the reciprocal connection between prices and quantities ([42], p. 168).

Assumption $3(\mathrm{~W})$. For all $\mathbf{p b} \in S_{n}, \mathbf{p z}(\mathbf{p})=0$ (Walras' Law). In what follows we shall need another, rather technical assumption.

Assumption 4 (C). The vector excess-demand function, $\mathbf{z}(\mathbf{p})$, is continuous over its domain of definition, $S_{n}$ ([3], p. 21).

From the arguments that Arrow and Hahn give for the third Assumption 3 ([3], p. 21) follows that the available quantity is completely used for any price, as if the existing quantity completely participated in the trade. Despite this, generally, only part of the existing quantity genuinely participates in trading. It is necessary to point out that Assumption 3-called "Walras' Law"-which is one of the crucial foundations of modern economic theory - both in macro and micro economics - as formulated by Lange [43]-[45], and modified by the modern authors, differs essentially from Walras's original laws [16], [46] and [47]. Moreover, it is an intermediate stage of Walras's own Laws, and there is a significant difference also between Lange's and modern authors' versions of "Walras' Law". Yet, Arrow and Hahn, themselves indicate that there is a certain inconsistency between assumption 3 (W) and assumption 4 (C) ([3], p. 21).

Before determining equilibrium let us discuss the basic theorem, despite the fact that Arrow and Hahn considered them in inverse order. They write:

Theorem 1. If $\mathrm{W}$ and $\mathbf{z}\left(\mathbf{p}^{*}\right) \leq \mathbf{0}$, then $z_{i}\left(\mathbf{p}^{*}\right)<0$ implies that $p_{i}^{*}=0 \quad$ ([3], p. 23).

This theorem is known as the free goods conception (non-classical) as it was formulated by post-Walras economists. We have discussed it in our works [1], and we have concluded that free goods conception is irrelevant to real contemporary economic life ${ }^{12}$. Yet, the free goods conception plays crucial importance in the proving of existence [36], [39], [48] and [49]. So, we can conclude that the proving of existence is based on free goods conception. In other words, without free goods conception proof of equilibrium existence could not be possible.

Also, problems of saving, investment, interest rate and money, and other economic problems are not discussed in this model. At the same time it must be noted that the above assumptions are varied throughout the Arrow-Hahn book. Despite this the "spirit" of these basic assumptions, in our opinion, remains unchanged. Therefore, we can conclude that the Arrow-Debreu general equilibrium model is irrelevant to real contemporary economic life ${ }^{13}$.

\section{Money Theory}

Classics, who considered money theory as essential to and inseparable from economic theory, have discussed their reciprocal influence. Smith discussed his monetary theory, not only in Book II, but also throughout the Wealth of Nations. Marx has repeatedly focused on his money theory throughout the four volumes of his Capital. One of Walras's major and unique contributions is the integration of his money theory into his general equilibrium theory which enabled him to consider the real economic and financial sector as one integrated system ${ }^{14}$. Schumpeter stated, let to repeat, that "In the same sense in which it is true to say that he (Walras-E.D.) created economic statics, the modern theory of economic equilibrium, it is also true to say that he created the modern theory of money. In fact, his theory of money and credit is simply part of this general theory of economic equi-

\footnotetext{
${ }^{12}$ Some modern authors are familiar with the fact that the conception of free goods is irrelevant to real economic life ([67], pp. 11-12; [68], p. 9). Nevertheless, in proving existence, both authors continue using the free goods conception and to overcome the flaw of free goods conception.

${ }^{13}$ Allais wrote: “Any theory whatever, if it is not verified by empirical evidence, has no scientific value and should be rejected” ([69], p. 26).

14“'Walras's 'cash-balance' theory of money is both valuable in itself and remarkable in the way it is integrated into his general equilibrium system” ([60], p. 209).
} 
librium” ([5], p. 1082).

Majority of economists since Pareto, unfortunately, misunderstood and misinterpreted Walras's general equilibrium theory, especially, theory of money, and have been claiming that Walras's theory is both incomplete and even wrong [8], or that the problem of money is not discussed by him at all. Economists, who realized that Walras discussed the problem of money in his theory, are claiming that he failed in the integration of money in his general equilibrium theory ${ }^{15}$. Therefore, they have been attempting to reconstruct and rewrite it. Moreover, from the very beginning, Walras's money theory is simply ignored.

Crucial attribute of Walras's money theory, which was completely misunderstood and was absolutely given up, yields serious confusion: is the fact that Walras as well as Smith considered two types of money: money as a medium of exchange, a measure of value and store of value where the money commodity (numéraire) has to be served and money for circulation where either the money commodity (numéraire) or fiat money might be served. Thus, there are two different prices for the money commodity: a) when money commodity is used as a measure of value its price equal to one; b) when money commodity is used in circulation its price equal to the rate of interest.

In contrast, in the works of most post-Walras economists, the economic and financial sectors are separated, and their authors have been claiming that money commodity (numéraire) is not money ([9], p. 3). Walras foresaw such misunderstanding his money theory therefore emphasized that "In general, however, the commodity which serves as the numeraire serves also as money and acts as a medium of exchange. The standard of measure of value thus becomes the monetary standard. The two functions are, nevertheless, distinct, even when they are found in the same commodity” ([2], p. 189).

Therefore, is not accidental that post-Walras's money theory is generally considered one type of money-fiat money. Moreover, in the modern general equilibrium theory, money either disappeared or is considered in very simplified form and with unrealistic assumptions.

\subsection{Walras's Money Theory}

Asserting that "The role of money in the economy of the social body is as important as that of blood in the human body," Walras realized that money theory and the related issues play a crucial role in any economy, but especially in modern economics ([15], p. 312). Therefore, in the very beginning of writing of Elements the theory of money was the central topic of his general equilibrium theory ([2], p. 54). Furthermore, the theory of money was significantly improved for the definitive fourth edition of the Elements "it was my theory of money that underwent the most important changes" ([2], p. 38).

Walras's distinction between money commodity (numéraire) and money (for circulation) has been the cause of a certain amount of confusion [50]. For example, there are many economists, who claim that Walras's GET is only a barter exchange economy and money does not play any role. Majority of authors identifying fiat money with money and modern theory used only fiat money. I addition, if we take into account the fact that the contemporary world economy is governed by fiat money, the issue of the relationship between numéraire and money becomes crucial not only in order to understand Walras's monetary theory, but also to understand modern money theory as in general.

Classics distinguished between the functions of money and money as a service. Money has the following functions: 1) measure of value; 2) medium of exchange (payment); 3) a store of value; and 4) it is used as world money. Walras, in his general equilibrium theory considered only the closed economy and therefore the last function of money was not discussed. The first three functions of money are carried out by the money commodity (numéraire), and it is used in such role for all four economies. Walras used money as a service for lending and borrowing only for high level economy_circulation and money ([2], p. 270).

Walras realized the property of money, as a service, entirely in the last economy, Circulation and Money, where money is also used as a service of circulation ([2], p. 317). This means that in the calculation in the equation of the cost of production of the produced goods the price of a certain product used as a circulation capital is determined as a price of product in question multiple a price of money's service, the rate of interest (vide supra).

So, according to Walras's approach there are two different types of money. The first type of money for accomplishing the functions of money, and its price is one. The second type of money is used as its service for circulation, and its price is the rate of interest. Walras used fiat money only as the second type, whilst the money

\footnotetext{
15“'In particular, the best-developed modern Walrasian general equilibrium models cannot find room for money” [63] [70].
} 
commodity (numéraire) might be used in both. In addition, it is necessary to stress that these types of money must be used simultaneously. This means that numéraire and fiat money ought to co-exist and serve economic functions. Therefore, fiat money cannot substitute money commodity, i.e., fiat money cannot stand alone. Moreover, the quantity of fiat money is linked with the quantity of the money commodity used as numéraire ([51], p. 284; see also p. 288 and p. 290). From this we might conclude that numéraire could be used instead of fiat money, but fiat money cannot serve as numéraire, i.e., fiat money never fulfills the first three functions of money in the general sense and therefore numéraire and fiat money must be used simultaneously.

One of crucial achievements of Walras's general equilibrium theory is reciprocal interconnection between micro and macroeconomics, i.e., exchanging information between them in the iterative process (tâtonnement) of equilibrium establishment. The same is true for the money theory of Walras.

By means of solution of the model of individual (micro) the three categories of money are obtained and used in macro model (vide supra):

1) The demand of money commodity for consumption, in terms of money commodity (numéraire).

2) Either the demand or the supply of income commodity for saving, in terms of money commodity.

3) The supply of money for circulation (cash) in production, in terms of either money commodity or paper money, which is determined as the difference between the available quantity of money (cash) minus the demand for money and money for savings from the side of consumers ${ }^{16}$.

By the aggregation of the results for all individuals the total demand for money commodity, the total demand for saving (income commodity), and the total supply of money for circulating is determined. On the other hand, in the macro level the total supply of money commodity, the total demand for investment determined by entrepreneurs and the total demand for money for circulation has to be determined. Yet, in the macro model, the cost of production for the money commodity is also calculated similarly to other products for consumption.

The effective demand and the effective supply of money, at each iteration, for a certain price of the service of money, are compared to each other and if there is equality between them, i.e., there is equilibrium. In case of inequality, however, the new price of the service of money (the rate of interest) is determined according to relation between them. This process is similar to Walras's law of equilibrium establishment for circulation and money: "The price of the service of money is established through its rise or fall according as the desired cash balance is greater or less than the quantity of money" (italics original) ([2], p. 327).

So, the information, which is passed to micro economics from macro, includes three prices (vide supra):

1) the price of the money commodity, which in equilibrium is equal to one;

2) the rate of income;

3) the rate of interest. It must be emphasized that Walras assumed that in equilibrium the rate of income is equal to the rate of interest.

The mutual exchange information between macro and micro economics continues as long as either general equilibrium is established, or it becomes clear the equilibrium is not achievable in the framework of assumptions and in light of the initial data, which is not varied during the iterative process of equilibrium establishment. However, if equilibrium might be established, individuals who find themselves out of equilibrium state might change their initial data (parameters of utility functions and the available quantities of services and products). In such a case, therefore, Walras considered re-establishment of equilibrium. Since such changing might have a permanent character, general equilibrium is never achieved, which this means that real economics is in a constant state of disequilibrium. As Walras has repeatedly stated: "The state of equilibrium, to which real markets always tend without ever attaining it” ([15], p. 365; see also [2], p. 380). This means that applied theory deals with a situation when conditions of equilibrium are destroyed. In the world of Pure Theory where the regime of free competition is governed such distortion will be automatically transformed to new equilibrium. But since in the real world such markets as monopoly, oligopoly and, as well as free competition are involved, this kind of distortion would be persistent. In order to minimize this distortion of equilibrium, Walras proposed the State's intervention ([15], pp. 372-373). The important issue here is in which cases and to what degree must or should the State intervene [52].

Walras emphasized the specific role of money in distortion of general equilibrium because that changing of price of money impacts directly on prices of almost all products. Hence, changing price of money yields chang-

\footnotetext{
${ }^{16}$ Therefore, we cannot agree with Siven who states that "In a Walrasian general equilibrium model, we would ordinarily expect one equilibrium condition for each market. The number of independent equilibrium conditions will, via Walras's law, be one fewer than the total number of markets” ([71], p. 687; see also [72], [73]).
} 
ing prices of products and the result is a disorder of equilibrium. Walras stated:

"This general disorder of the economic equilibrium is called a crisis. Theoreticians of the orthodox school strive in vain to convince us that 'money is a commodity like any other'; it is not commodity like any other when each variation in either its utility or its price provokes a crisis. ... I mean to convey when I vaunt the advantages of price stability” ([15], p. 84).

In the case of deep crises Walras recommended that the State should intervene and regulate the quantity of money: "Therefore the state should issue the money and, if necessary, regulate the production of precious metals according to the country's needs and prohibit or make rules for the issue of banknotes and the use of account money” ([15], p. 373).

\subsection{Modern Money Theory}

Since the seventies, the majority of countries have been using the fiat money as standard money; hence, fiat money replaced the money commodity and had to fulfill all four functions of money ${ }^{17}$. But this is opposes the principal statement of classical money theory, according to which only money commodity have to serve as a measure of value, and fiat money has to be used for circulating. Moreover, the quantity of fiat money must be regularized by the quantity of the money commodity (vide supra).

Theoretical and practical backgrounds for that process, unfortunately, were not properly discussed. As both Friedman, the guru of monetarism and Nobel Prize laureate, and Schwartz have written: "Unfortunately, there are currently legal obstacles to any developments that would enable gold to be used not only as a store of value or part of an asset portfolio but as a unit of account or a medium of circulation. Hence, the current situation provides little evidence on what would occur if those obstacles were removed" ([53], p. 47). To the best of our knowledge, unfortunately, they did not reveal here or anywhere else, what kind of "legal obstacles" they refer to because they do not exist. So, modern economics is "governed" by fiat money, namely by American dollar.

The replacement of the money commodity by the fiat money has yielded several phenomena, predecessors of the current financial bubbles. First, because the fiat money has no objective value, economics (markets) have managed without valuating goods and services. Second, because there is only one type of money, namely fiat money, there is only one price - the price of the service of money (the rate of interest) while the price of the money served as a measure of value (equal to one) is absent. Therefore, this is another reason why fiat money cannot be served as a measure of value. Third, there are no obstacles and no limit to printing paper money.

Modern theory of money is generally concentrated on the macroeconomic level [54] [55]; despite that, it is convenient that the modern microeconomic theory has been compatible with reality rather than with macroeconomic theory. However, since Walras, unfortunately, microeconomics theory has not developed from the point of view of money theory. Let us to elucidate our above mentioned argumentation using the well-known paper of Clower [56] "A Reconsideration of the Microfoundations of Monetary Theory"18. Here Clower has identified post-Walras theory of money with Walras's theory, such that if the modern theory is incorrect then the same is true for Walras's theory ([56], p. 81). However, fortunately, this statement of Clower and other authors is generally mistaken (vide infra). This is a clear example of the modern authors' blaming Walras's theory for using incorrect theories by other modern economists.

Clower, first, discusses the model of the modern authors ([56], p. 82). This model differs from Walras's model of individual's economy in Exchange economy: first, Walras used fiat money only in the last economyCirculation and Money, in the previous three economies the money commodity is served as money. Second, fiat money is valueless and useless; therefore, it has no direct utility and cannot appear in the utility function. Third, Walras manipulated the demand and supply of all categories, later obtaining the final endowment by their means. Clower and consequently Hicks, Lange, and Patinkin use initial and final endowment, which allows calculating demand and supply. Finally, the utility function includes all goods simultaneously while Walras considered utility function for each good separately.

Clower states that the conclusion in the discussing model "indicates that money plays no distinctive role in

${ }^{18}$ It is ironic that Baumol, who has been claming that Walras's mathematics is primitive, has created a much poorer model, and this writing more than a century after Walras. Baumol writes “Then, using obvious notation, equilibrium requires (1) $\operatorname{Max} \Sigma p_{i} y_{i}-C\left(y_{1}, \cdots, y_{n}\right)$; subject to (2) $\Sigma p_{i} y_{i}-C\left(y_{1}, \cdots, y_{n}\right) \leq k$ (where we will select $\left.k=0\right)$ ) ([74], p. 15).
} 
economic activity” ([56], p. 83). Therefore, he suggests using the money commodity ([56], p. 85). Then, he presents his own, alternative model where there is "a clear separation between goods demanded for purchase (offers to sell money) and goods offered for sale (offers to buy money)" ([56], p. 86). The result is that "the budget constraint equation is divided into two constraints: a) a constraint on money expenditure and b) a constraint on money income" ([56], pp. 87-88).

Such a division is artificial and incompatible with reality, because in practice expenditure and income are mutually connected. So, Clower's statement that "the total value of goods demanded cannot be in any circumstances exceed the amount of money held by the transactor at the outlet of the period" ([56], p. 87) is doubtful. Clower continues, "I shall refer henceforth to $m_{j}$ as the income demand for money, to $M$ as the reservation demand for money. Such a separation of income and reservation demands has no place in accepted equilibrium models," ([56], p. 87). This statement of Clower is correct in the relation to models of post-Walras's authors; however, it is incorrect in relation to Walras's model. The micro model for an individual of Walras' last economy includes not only the reservation-demand for money (demand for the money commodity) and the income demand for money (saving), but also the supply of money to production for circulation (vide supra).

Finally, and more importantly, Clower does not discuss the connection (relationship) between micro and macro economics.

On the other hand, the modern theory formally determines the rate of interest similar to the classical approach; namely, according to modern theory the rate of interest is determined by the relationship between aggregate demand and aggregate supply of money. However, there are essential differences between them, since the modern theory of interest is based on the Keynes's approach [57]. Moreover, the differences are deepened. For example, the supply of money depends not only on the quantity of printed money as well as Keynes's approach but also on the rate of the money multiplier. Yet, the modern theory of money continues determining the demand function for money as an inverse function of income according to Keynes, the existence of which is doubtful.

\section{Conclusions}

In this paper it was shown that one of crucial causes of contemporary financial-economic crisis is an abandonment of the classic and Walras's theories, in particular the monetary theory. Therefore, three fundamental differences between Walras's and modern economists' approaches were discussed and demonstrating the latter to be incompatible with hypothetical economics whilst the first applies well to its era's reality.

First, classics assumed that the theory has to be close to reality but never be its copy. For example, Walras stated that in reality general economic equilibrium can never be achieved but his theory illustrates how it might be established. On the other hand, modern authors have not merely assumed that theory may diverge from reality, they've taken it to the extreme: "the more significant the theory, the more unrealistic assumptions". In the paper six unrealistic and incorrect assumptions are considered.

Second, using of mathematics in economic theory, Walras was the first who used mathematics to describe interdependence between various parts of whole economy. His use of mathematics is both effective and impressive, and is based on the latest achievements of his time while trying to explore a new direction. This is opposite of the modern mathematician-economists asserting that Walras's mathematics is "primitive, clumsy, dubious, and even incorrect”. Six erroneous claims have been made against Walras's mathematics.

In the paper, Walras's mathematical model for the individual's economy (micro model) is drawn for the circulation and money economy, in the first time, and its some special attributes are signified; it is his significant achievement and is the best micro model to this day.

Also, in the paper, Walras's two macro models are decrypted: a) the equilibrium model; and b) the disequilibrium model. Hence, Walras used his unique method of equilibrium establishment (tâtonnement), to transform disequilibrium state into equilibrium state.

In conclusion, Walras's statement, according to which the number of indipendent equations is equal to the number of unknowns in equilibrium state, is conceived after the equilibrium is established by iterative process (tatonnement), when the disequilibrium state is transformed in the equilibrium state; therefore, it is a necessary and satisfactory condition for equilibrium existence. However, since post-Walras's authors used this statement to establish equilibrium (solving the problem), it has become a neccessity, but not a satisfactory condition for equilibrium existence.

Whilst, modern mathematical models of economics and financial sectors are very complicated, however with the majority of them weakly connected with reality. The Arrow-Debreu model is discussed as a representative of 
the modern GET. It was shown that modern general equilibrium theory used several unrealistic assumptions; hence, its incompatibility with reality is clear. According to these unrealistic assumptions, the equilibrium price of some goods and services, specifically when these are in excess supply is equal to zero. For example, in an equilibrium situation, with high unemployment, wages have to be equal zero: "In a purely neoclassical version, permanent unemployment would require a zero wage" (Arrow \& Starrett, p. 241; see also Arrow, p. 18). However, such wages contradict reality economics. Therefore, the main achievement of modern general equilibrium theory (MGET), the proof of equilibrium existence basing on these assumptions, becomes completely meaningless.

Finally and perhaps most importantly, the "Walras' Law", formulated by post-Walras economists, is one of the crucial assumptions of the MGET and differs essentially from Walras's original laws. Moreover, it is an intermediate stage of Walras's own laws. The “Walras' Law”, unfortunately, has replaced Walras's original laws, subsequently, the latter have become relatively unknown and abandoned. The thought of an "alternate" to Newton's laws coexisting with the original is ludicrous, yet in economics such anomalies are common place.

So, modern general equilibrium theory diverged from representing the current financial sector, greatly simplifying the problem of money and loosing any ability to discuss the money quantity regulation problems. This is additional cause for the financial crisis.

Third, money theory, Walras succeed in integrating money theory into his general equilibrium theory which enabled him to consider real economic and financial sector as one whole system. According to Walras's approach there are two different types of money. The first type of money serving for the functions of money, and its price is one. The second type of money is used for circulation, and its price is the rate of interest. Walras used fiat money only as the second type, whilst the money commodity (numéraire) might be used in both. Thus, there are two different prices for the money commodity. Yet, this means that numéraire and fiat money ought to coexist and serve economic functions. Therefore, fiat money cannot substitute money commodity, i.e., fiat money cannot stand alone. Moreover, the quantity of fiat money is linked with the quantity of the money commodity used as numéraire.

One of crucial achievements of Walras's general equilibrium theory is reciprocal interconnection between micro and macroeconomics, i.e., exchanging information between them in the iterative process (tâtonnement) of equilibrium establishment. The same is true for the money theory of Walras. By means of solution of the model of individual (micro) the three categories of money are obtained and used in macro model: 1) The demand for money commodity for consumption; 2) Either the demand for or the supply of income commodity for saving; 3) The supply of money for circulation (cash) in production.

On the other hand, the information, which is passed to micro economics from macro, includes three prices: 1) the price of the money commodity, which in equilibrium is equal to one; 2 ) the rate of income; and 3) the rate of interest.

Walras emphasized the specific role of money in distortion of general equilibrium because that changing of price of money impacts directly on prices of almost all products and services. Hence, changing price of money yields changing prices of products and the result is a disorder of equilibrium, i.e., economic crisis. In the case of deep crises Walras recommended that the State should intervene and regulate the quantity of money.

On the other hand, in the works of most post-Walras economists economic and financial sectors are separated and these authors have been claiming that money commodity (numéraire) is not money. Therefore, it is not accidental that post-Walras's money theory is generally considered one type of money-fiat money.

The replacement of the money commodity by the fiat money has yielded several phenomena, predecessors of the current financial bubbles. First, because the fiat money has no objective value, economics (markets) is managed without valuating of goods and services. Second, because there is only one type of money, namely fiat money, there is only one price - the price of the service of money (the rate of interest), while the price of the money served as a measure of value (equal to one) is absent. Therefore, this is another reason why fiat money cannot be served as a measure of value. Third, there are no obstacles and no limit to printing paper money.

Modern theory of money is generally concentrated on the macroeconomic level; despite that, it is convenient that the modern microeconomic theory has been compatible with reality rather than with macroeconomic theory. Unfortunately, since Walras, microeconomics theory has not developed from the point of view of money theory. Microeconomic models are generally confined by the Exchange and sometimes Production Economies, and if money is integrated, then it is done superficially. In these models demand and supply of commodities might be indirectly determined by the relationship between the final endowment and the available initial endowment, but 
it is not done. These claims were elucidated using Clower's well-known paper.

On the other hand, the modern theory formally determines the rate of interest similar to the classical approach; namely, according to modern theory the rate of interest is determined by the relationship between aggregate demand and aggregate supply of money. However, there are essential differences between them. For example, the supply of money depends not only on the quantity of printed money as well as Keynes's approach but also on the rate of the money multiplier. Yet, the modern theory of money continues determining the demand function for money as an inverse function of income according to Keynes, the existence of which is doubtful.

\section{References}

[1] Davar, E. (1994) The Renewal of Classical General Equilibrium Theory and Complete Input-Output System Models. Avebury, Aldershot, Brookfield USA, Hong Kong, Singapore, Sydney.

[2] Walras, L. (1954) Elements of Pure Economics. Translated by Jaffe, W., Allen and Unwin, London.

[3] Arrow, K.J. and Hahn, F.H. (1971) General Competitive Analysis. Holden-Day, Inc., San Francisco.

[4] Debreu, G. (1959) Theory of Value. Wiley, New York.

[5] Schumpeter, J.A. (1954) History of Economic Analysis. Oxford University Press, New York.

[6] Marget, A.W. (1931) Leon Walras and the "Cash-Balance Approach" to the Problem of the Value of Money. Journal of Political Economy, 39, 569-600. http://dx.doi.org/10.1086/254248

[7] Marget, A.W. (1935) The Monetary Aspects of the Walrasian System. Journal of Political Economy, 43, 145-186. http://dx.doi.org/10.1086/254753

[8] Hicks, J.R. (1983) “Leon Walras”, Econometrica, and in Classics and Moderns. Basil Blackwell, Oxford.

[9] Hicks, J.R. (1967) Critical Essays in Monetary Theory. Clarendon Press, Oxford.

[10] Woodford, M. (2003) Interest and Prices: Foundations of a Theory of Monetary Policy. Princeton University Press, Princeton.

[11] Magill, M. and Quinzii, M. (1992) Real Effects of Money in General Equilibrium. Journal of Mathematical Economics, 21, 301-342. http://dx.doi.org/10.1016/0304-4068(92)90012-V

[12] Kiyotaki, N. and Wright, R. (1989) On Money as a Medium of Exchange. Journal of Political Economy, 97, $927-954$.

[13] Davar, E. (2013) Input-Output Analysis and Contemporary Economics. LAP Lambert.

[14] Marshall, A. (1930) The Pure Theory of Domestic Value. The London School of Economics, London.

[15] Walras, L. (2005) Studies in Applied Economics Theory of the Production of Social Wealth. Translated by van Daal, J., 2 Volumes, Routledge, London.

[16] Davar, E. (2012) Is “Walras’ Law” Really Walras’s Original Law? World Review of Political Economy, 3, 478-500. http://dx.doi.org/10.13169/worlrevipoliecon.3.4.0478

[17] Davar, E. (2011) Flaws of Modern Economic Theory: The Origins of the Contemporary Financial-Economic Crisis. Modern Economics, 2, 25-30.

[18] Davar, E. (2013) Government Spending and Economic Growth. The Finance and Business, 2, 4-19.

[19] Davar, E. (2014) How Flaws in the General Theory Render It Irrelevant to the Real World. Modern Economy, 5, 93104. http://dx.doi.org/10.4236/me.2014.51011

[20] Baumol, W.J. and Goldfeld, S.M. (1968) Precursors in Mathematical Economics: An Anthology. London School of Economics, London.

[21] Jaffé, W. (1968) Walras’s Economics as Other See It. In: Walker, D.A., Ed., William Jaffe’s Essays on Walras, Cambridge University Press, New York.

[22] Hicks, J.R. (1939-1946) Value and Capital. 2nd Edition, Clarendon Press, Oxford.

[23] Dorfman, R., Samuelson, A.P. and Solow, R.M. (1958) Linear Programming and Economic Analysis. McGraw-Hill Book Company, Inc., New York.

[24] Morishima, M. (1977) Walras’ Economics: A Pure Theory of Capital and Money. Cambridge University Press, New York.

[25] Blaug, M. (1997) Ugly Currents in Modern Economics. Policy Options.

[26] Leijonhufvud, A. (2008) Moving on: Where to? In: Forstater, M. and Wray, L.R., Eds., Keynes for the Twenty-First Century, Palgrave Macmillan, Basingstoke.

[27] Van Daal, J. and Jolink, A. (1993) The Equilibrium Economics of Leon Walras. Routledge, New York. 
http://dx.doi.org/10.4324/9780203401460

[28] Cassel, G. (1967) The Theory of Social Economy. Augustus M. Kelley Publishers, New York.

[29] Schlesinger, K. (1968) On the Production Equations of Economic Value Theory. Baumol and Goldfeld.

[30] Wald, A. (1968) On the Unique-Negative Solvability of New Production Equations. Baumol and Goldfeld.

[31] van Daal, J. and Walker, D.A. (1990) The Problem of Aggregation in Walras's General Equilibrium Theory. History of Political Economy, 22, 489-505. http://dx.doi.org/10.1215/00182702-22-3-489

[32] Walker, D. (1996) Walras’s Market Models. Cambridge University Press, Cambridge. http://dx.doi.org/10.1017/CBO9780511664502

[33] Walker, D.A. (2006) Walrasian Economics. Cambridge University Press, New York. http://dx.doi.org/10.1017/CBO9780511510748

[34] Samuelson, P.A. (1947) Foundations of Economic Analysis. Harvard University Press, Cambridge.

[35] Mas-Colell, A., Whinston, M.D. and Green, J.R. (1995) Microeconomic Theory. Oxford University Press, New York.

[36] Ingrao, B. and Israel, G. (1990) The Invisible Hand Economic Equilibrium in the History of Science. MIT Press, Cambridge.

[37] Shoven, J.B. and Whalley, J. (1993) Applying General Equilibrium. Cambridge University Press, New York.

[38] Rosenberg, A. (1993) If Economics Isn’t Science, What Is It? In: The Philosophy and Methodology of Economics III, Edward Elgar, Aldershot.

[39] Arrow, K.J. (1989) Von Neumann and the Existence Theorem for General Equilibrium. In: Dore, M., Chakravarty, S. and Goodwin, R., Eds., John von Neumann and Modern Economics, Clarendon Press, Oxford.

[40] Pareto, V. (1971) Manual of Political Economy. Translated by Schwier, A.S., Macmillan, London.

[41] Allen, R.D. (1960) Mathematical Economics. MacMillan, London.

[42] Dierker, H. and Grodal, B. (1986) Non-Existence of Cournot-Walras Equilibrium in a General Equilibrium Model with Two Oligopolists. In: Hildenbrand, W. and Mas-Colell, A., Eds., Contributions to Mathematical Economics, NorthHolland, Amsterdam, 167-186.

[43] Lange, O. and Taylor, F.M. (1938) On the Economic Theory of Socialism. In: Lippincott, B.E., Ed., The University of Minnesota Press, Minnesota.

[44] Lange, O. (1942) Say’s Law: A Restatement and Criticism. In: Lange, O., et al., Eds., Studies in Mathematical Economics and Econometrics, Cambridge University Press, Cambridge, 49-68.

[45] Patinkin, D. (1989) Money, Interest, and Prices. 2nd Edition, Massachusetts Abridged, MIT Press, Cambridge.

[46] Walras, L. (2005) Studies in Applied Economics Theory of the Production of Social Wealth. European Journal of Political Economy, 22, 1016-1019.

[47] Davar, E. (2008) Review of Walrasian Economics. European Journal of Political Economy, 24, 713-715.

[48] Weintraub, E.R. (1985) General Equilibrium Analysis Studies in Appraisal. Cambridge University Press, Cambridge.

[49] Schwödiauer, G. and Reidel, D. (1978) Equilibrium and Disequilibrium in Economic Theory. Dordrecht-Holland, Boston.

[50] Negishi, T. (1989) History of Economic Thought. North-Holland, New-York.

[51] Smith, A. (1937) The Wealth of Nations. Random House Inc., New York.

[52] Potier, J.P. (1998) Leon Walras and Applied Science. In: Faccarello, G., Ed., Studies in the History of French Political Economy, Routledge, London.

[53] Friedman, M. and Schwartz, A.J. (1986) Has Government Any Role in Money? Journal of Monetary Economics, 17, 37-62. http://dx.doi.org/10.1016/0304-3932(86)90005-X

[54] Ahiakpor, J.C.W. (2003) Classical Macroeconomics. Routledge, London.

[55] Chick, V. (1983) Macroeconomics after Keynes, a Reconsideration of the General Theory. The MIT Press, Cambridge.

[56] Clower, R.W. (1967) A Reconsideration of the Microfoundations of Monetary Theory. Western Economic Journal, 6, 1-8.

[57] Keynes, J.M. (1960-1936) The General Theory of Employment Interest and Money. Macmillan, London.

[58] Laidler, D. (1999) The Foundations of Monetary Economics. EE Published.

[59] Bliss, Ch., et al. (2005) Capital Theory. EE Published.

[60] Hutchison, T.W. (1962) A Review of Economic Doctrines 1879-1929. The Clarendon Press, Oxford.

[61] Menard, C. (1990) The Lausanne Tradition: Walras and Pareto. In: Hennings, K. and Samuels, W.J., Eds., Neoclassical 
Economic Theory, 1870 to 1930, Kluwer Academic Publishers, London, 95-150. http://dx.doi.org/10.1007/978-94-009-2181-8_4

[62] Allingham, A. (1973) Quantitative Analysis of Economic Interaction. Ballinger PC, Cambridge.

[63] Bridel, P. and Huck, E. (2002) Yet Another Look at Léon Walras's Theory of tâtonnement. European Journal of the History of Economic Thought, 9, 513-540.

[64] Makarov, V.L., Levin, M.J. and Rubinov, A.M. (1995) Mathematical Economic Theory. North-Holland, Elsevier, Amsterdam, New York.

[65] Backhaus, J. and Maks, H. (2009) From Walras to Pareto. Springer, Berlin.

[66] ten Raa, T. (2010) Input-Output Economics: Theory and Applications. World Scientific Publishing Co. Pte. Ltd., Singapore.

[67] Morishima, M.M. (1992) Capital, and Credit: A New Formulation of General Equilibrium Theory. Cambridge University Press, Cambridge. http://dx.doi.org/10.1017/CBO9780511628467

[68] Ginsburgh, V. and Keyzer, M. (1997) The Structure of Applied General Equilibrium Models. MIT Press, Cambridge.

[69] Allais, M. (1992) The Economic Science of Today and Global Disequilibrium. In: Baldassarri, M., McCallum, J. and Mundell, R., Eds., Global Disequilibrium in the World Economy, the Macmillan Press Ltd., London.

[70] Bridel, P. (1997) Money and General Equilibrium Theory. Edward Elgar, UK, USA.

[71] Siven, C.H. (2006) Monetary Equilibrium. History of Political Economy, 38, 665-706. http://dx.doi.org/10.1215/00182702-2006-016

[72] Weintraub, E.R. (2002) How Economics Became a Mathematical Science. Duke University Press, Durham. http://dx.doi.org/10.1215/9780822383802

[73] Debreu, G. (1991) The Mathematization of Economic Theory. The American Economic Review, 81, 1-7.

[74] Baumol, W. (2007) Entrepreneurship and Innovation: The (Micro) Theory of Price and Profit. File: Entpricetheory-w-apr-4-2007. 


\section{Appendix I. Walras's Equilibrium Macroeconomic Model with Fiat Money for Circulation and Money}

1) The system of $n$ equations of the aggregate offer of services (landed, personal, and fixed capital respectively) for the production of products:

$$
\begin{aligned}
O_{j}= & F_{j}\left(p_{2}, p_{3}, \cdots, p_{m} ; p_{1}^{t}, p_{2}^{t}, \cdots, p_{t}^{t} ; p_{1}^{p}, p_{2}^{p}, \cdots, p_{p}^{p} ; p_{1}^{k}, p_{2}^{k}, \cdots, p_{l}^{k} ; p_{e} ;\right. \\
& \left.\quad p_{1^{\prime}}, p_{2^{\prime}}, \cdots, p_{m^{\prime}} ; p_{1^{\prime}}^{m}, p_{2^{\prime}}^{m}, \cdots, p_{s^{\prime}}^{m} ; p_{u^{\prime}} ; i\right) \\
= & \sum_{r=1}^{R} o_{j}^{r}-\Sigma_{r=1}^{R} d_{j}^{r} \quad(j=1,2, \cdots, n) ;
\end{aligned}
$$

2) The system of $m$ equations for the aggregate offer of the circulating capital goods services

$$
\begin{aligned}
O_{i^{\prime}}= & F_{i^{\prime}}\left(p_{2}, p_{3}, \cdots, p_{m} ; p_{1}^{t}, p_{2}^{t}, \cdots, p_{t}^{t} ; p_{1}^{p}, p_{2}^{p}, \cdots, p_{p}^{p} ; p_{1}^{k}, p_{2}^{k}, \cdots, p_{l}^{k} ; p_{e} ;\right. \\
& \left.p_{1^{\prime}}, p_{2^{\prime}}, \cdots, p_{m^{\prime}} ; p_{1^{\prime}}^{m}, p_{2^{\prime}}^{m}, \cdots, p_{s^{\prime}}^{m} ; p_{u^{\prime}} ; i\right) \\
= & \Sigma_{r=1}^{R} o_{i^{\prime}}^{r}-\Sigma_{r=1}^{R} d_{i^{\prime}}^{r}, \quad\left(i^{\prime}=1, \cdots, m\right) ;
\end{aligned}
$$

3) One equation of the money offer for circulation

$$
\begin{aligned}
O_{u}= & F_{u}\left(p_{2}, p_{3}, \cdots, p_{m} ; p_{1}^{t}, p_{2}^{t}, \cdots, p_{t}^{t} ; p_{1}^{p}, p_{2}^{p}, \cdots, p_{p}^{p} ; p_{1}^{k}, p_{2}^{k}, \cdots, p_{l}^{k} ; p_{e} ;\right. \\
& \left.p_{1^{\prime}}, p_{2^{\prime}}, \cdots, p_{m^{\prime}} ; p_{1^{\prime}}^{m}, p_{2^{\prime}}^{m}, \cdots, p_{s^{\prime}}^{m} ; p_{u^{\prime}} ; i\right) \\
= & Q_{u}-\left(\sum_{r=1}^{R} d_{i^{\prime \prime}}^{r} p_{i^{\prime \prime}}+d_{e^{\prime}} p_{1}\right) / p_{u^{\prime}}
\end{aligned}
$$

4) The system of $m$ equations for the aggregate demand for products:

$$
\begin{aligned}
& D_{i}=F_{i}\left(p_{2}, p_{3}, \cdots, p_{m} ; p_{1}^{t}, p_{2}^{t}, \cdots, p_{t}^{t} ; p_{1}^{p}, p_{2}^{p}, \cdots, p_{p}^{p} ; p_{1}^{k}, p_{2}^{k}, \cdots, p_{l}^{k} ; p_{e} ;\right. \\
& \left.\quad p_{1^{\prime}}, p_{2^{\prime}}, \cdots, p_{m^{\prime}} ; p_{1^{\prime}}^{m}, p_{2^{\prime}}^{m}, \cdots, p_{s^{\prime}}^{m} ; p_{u^{\prime}} ; i\right) \\
& =\sum_{r=1}^{R} x_{i}^{r}, \quad(i=2,3, \cdots, m) ; \\
& D_{1}=\sum_{j=1}^{t} O_{j}^{t} p_{j}^{t}+\sum_{j=1}^{l} O_{j}^{l} p_{j}^{l}+\sum_{j=1}^{k} O_{j}^{k} p_{j}^{k}+\Sigma_{s=1}^{S} Q_{s}^{m} p_{s}^{m}+O_{u} p_{u^{\prime}}-\left(\sum_{i=2}^{m} D_{i} p_{i}+E\right) ;
\end{aligned}
$$

5) One equation of the aggregate excess of income over consumption

$$
\begin{gathered}
E=D_{e} p_{e}=F_{e}\left(p_{2}, p_{3}, \cdots, p_{m} ; p_{1}^{t}, p_{2}^{t}, \cdots, p_{t}^{t} ; p_{1}^{p}, p_{2}^{p}, \cdots, p_{p}^{p} ; p_{1}^{k}, p_{2}^{k}, \cdots, p_{l}^{k} ;\right. \\
\left.p_{e} ; p_{1^{\prime}}, p_{2^{\prime}}, \cdots, p_{m^{\prime}} ; p_{1^{\prime}}^{m}, p_{2^{\prime}}^{m}, \cdots, p_{s^{\prime}}^{m} ; p_{u^{\prime}} ; i\right)
\end{gathered}
$$

6) The system of $n$ equations of equality between the total quantities of productive services required (demanded) and their total effective offer quantities for production:

$$
\sum_{i=1}^{m} a_{j i}\left(D_{i}+D_{i^{\prime}}\right)+\sum_{s=1}^{S} a_{j s} D_{s}^{m}+\sum_{j_{3}=1}^{m} a_{j j_{3}} D_{j_{3}}^{k}=\left(D_{j}\right)=O_{j}, \quad(j=1,2, \cdots, n),
$$

7) The system of $m$ equations of equality between the total required (demanded) quantities of circulating capital goods and their total effective offer quantities for production:

$$
\sum_{i=1}^{m} a_{i^{\prime} i}\left(D_{i}+D_{i^{\prime}}\right)+\sum_{s=1}^{S} a_{i^{\prime} s} D_{s}^{m}+\sum_{j_{3}=1}^{n} a_{i^{\prime} j_{3}} D_{j_{3}}^{k}=\left(D_{i^{\prime}}^{r}\right)=O_{i^{\prime}}, \quad\left(i^{\prime}=1,2, \cdots, m\right)
$$

8) The system of $S$ equations of equality between the offer (available quantities) of raw materials and their demand in production:

$$
\sum_{i=1}^{m} a_{s i}\left(D_{i}+D_{i^{\prime}}\right)+\sum_{s=1}^{S} a_{s s} D_{s}^{m}+\sum_{j_{3}=1}^{n} a_{s j_{3}} D_{j_{3}}^{k}=\left(D_{s}^{r m}\right)=Q_{s}^{m}, \quad(s=1,2, \cdots, S)
$$

9) One equation of equality between the demand for and offer of the money services in circulation

$$
\sum_{i=1}^{m} \delta_{i^{\prime}} p_{i^{\prime}}+\sum_{s=1}^{S} \delta_{s}^{m} p_{s^{\prime}}^{m}+\sum_{j_{3}=1}^{k} \delta_{j_{3}}^{k} p_{j_{3}}^{k}=\left(D_{u} p_{u^{\prime}}\right)=O_{u} p_{u^{\prime}},
$$

10) The system of $m$ equations of equality between the selling prices of the products and the cost of the productive services employed in their production ${ }^{18}$ : 


$$
\sum_{j_{1}=1}^{t} a_{j_{1} i}^{t} p_{j_{1}}^{t}+\sum_{j_{2}=1}^{p} a_{j_{2} i}^{p} p_{j_{2}}^{p}+\sum_{j_{3}=1}^{l} a_{j_{3} i}^{k} p_{j_{3}}^{k}+\sum_{i^{\prime}=1}^{m} a_{i^{\prime} i} p_{i^{\prime}}+\sum_{s=1}^{S} a_{s i} p_{s^{\prime}}+a_{u i} p_{i^{\prime}}=\left(p_{i}\right)=\pi_{i}, \quad(i=1,2, \cdots, m),
$$

where $p_{1}=\left(\pi_{1}\right)=1$;

11) The system of $l$ equations of equality between the selling prices of the new capital goods and their costs of production:

$\sum_{j_{1}=1}^{t} a_{j_{1} j}^{t} p_{j_{1}}^{t}+\sum_{j_{2}=1}^{p} a_{j_{2} j}^{p} p_{j_{2}}^{p}+\sum_{j_{3}=1}^{l} a_{j_{3} j}^{k} p_{j_{3}}^{k}+\sum_{i^{\prime}=1}^{m} a_{i^{\prime} j} p_{i^{\prime}}+\sum_{s=1}^{S} a_{s j} p_{s^{\prime}}+a_{u j} p_{u^{\prime}}=\left(P_{j_{3}}^{k}\right)=\Pi_{j_{3}}^{k}, \quad\left(j_{3}=1,2, \cdots, l\right)$,

12) The system of $S$ equations of equality between the selling prices of raw materials and their cost of production $\sum_{j_{1}=1}^{t} a_{j_{1} s}^{t} p_{j_{1}}^{t}+\sum_{j_{2}=1}^{p} a_{j_{2} s}^{p} p_{j_{2}}^{p}+\sum_{j_{3}=1}^{l} a_{j_{3} s}^{k} p_{j_{3}}^{k}+\sum_{i^{\prime}=1}^{m} a_{i^{\prime} s} p_{i^{\prime}}+\sum_{s=1}^{S} a_{s s} p_{s^{\prime}}+a_{u s} p_{i^{\prime}}=\left(p_{s}^{m}\right)=\pi_{s}^{m}, \quad(s=1,2, \cdots, S)$,

13) One equation of equality between the total of new capital goods (investment) and aggregate excess of income over consumption (serving):

$$
\begin{aligned}
& \sum_{j_{3}=1}^{k} D_{j_{3}}^{k} P_{j_{3}}^{k}+\sum_{i^{\prime}=1}^{m} D_{i^{\prime}} p_{i^{\prime}}+\sum_{s=1}^{S} D_{s}^{m} p_{s}^{m}=\left(D^{k}\right)=(E) \\
& =F_{e}\left(p_{2}, p_{3}, \cdots, p_{m} ; p_{1}^{t}, p_{2}^{t}, \cdots, p_{t}^{t} ; p_{1}^{p}, p_{2}^{p}, \cdots, p_{p}^{p} ; p_{1}^{k}, p_{2}^{k}, \cdots, p_{l}^{k} ;\right. \\
& \left.\quad p_{e} ; p_{1^{\prime}}, p_{2^{\prime}}, \cdots, p_{m^{\prime}} ; p_{1^{\prime}}^{m}, p_{2^{\prime}}^{m}, \cdots, p_{s^{\prime}}^{m} ; p_{u^{\prime}} ; i\right),
\end{aligned}
$$

14) The system of $l$ equations the uniformity of the rate of net income for all new capital goods proper:

$$
P_{j_{3}}^{k}=\frac{p_{j_{3}}^{k}}{\left(i+\mu_{j 3}+v_{j_{3}}\right)}=\left(\Pi_{j_{3}}^{k}\right), \quad\left(j_{3}=1,2, \cdots, l\right)
$$

15) The equations system of prices for circulating capital goods, raw materials, and money in circulation:

$$
p_{i}=\frac{p_{i^{\prime}}}{i}, \quad(i=1,2, \cdots, m) ; \quad p_{s}^{m}=\frac{p_{s^{\prime}}^{m}}{i}, \quad(s=1,2, \cdots, S) ; \quad p_{u}=\frac{p_{u^{\prime}}}{i}
$$

\section{Appendix II. Walras's Disequilibrium Macroeconomic Model with Fiat Money for Circulation and Money}

The first five equation systems (3.2-1)-(3.2-5) are unchangeably included.

$$
\begin{gathered}
\sum_{i=1}^{m} a_{j i}\left(D_{i}+D_{i^{\prime}}\right)+\sum_{s=1}^{S} a_{j s} D_{s}^{m}+\sum_{j_{3}=1}^{m} a_{j_{3} j} D_{j_{3}}^{k}=D_{j} \neq O_{j}, \quad(j=1,2, \cdots, n), \\
\sum_{i=1}^{m} a_{i^{\prime} i}\left(D_{i}+D_{i^{\prime}}\right)+\sum_{s=1}^{S} a_{i^{\prime} s} D_{s}^{m}+\sum_{j_{3}=1}^{n} a_{i^{\prime} j_{3}} D_{j_{3}}^{k}=D_{i^{\prime}}^{r} \neq O_{i^{\prime}}, \quad\left(i^{\prime}=1,2, \cdots, m\right) \\
\sum_{i=1}^{m} a_{s i}\left(D_{i}+D_{i^{\prime}}\right)+\sum_{s=1}^{S} a_{s s} D_{s}^{m}+\sum_{j_{3}=1}^{n} a_{s j_{3}} D_{j_{3}}^{k}=D_{s}^{r m} \neq Q_{s}^{m}, \quad(s=1,2, \cdots, S) \\
\sum_{i=1}^{m} \delta_{i^{\prime}} p_{i^{\prime}}+\sum_{s=1}^{S} \delta_{s}^{m} p_{s^{\prime}}^{m}+\sum_{j_{3}=1}^{k} \delta_{j_{3}}^{k} p_{j_{3}}^{k}=D_{u} p_{u^{\prime}} \neq O_{u} p_{u^{\prime}}, \\
\sum_{j_{1}=1}^{t} a_{j_{1} i}^{t} p_{j_{1}}^{t}+\sum_{j_{2}=1}^{p} a_{j_{2} i}^{p} p_{j_{2}}^{p}+\sum_{j_{3}=1}^{l} a_{j_{3} i}^{k} p_{j_{3}}^{k}+\sum_{i^{\prime}=1}^{m} a_{i^{\prime} i} p_{i^{\prime}}+\sum_{s=1}^{S} a_{s i} p_{s^{\prime}}+a_{u i} p_{i^{\prime}}=p_{i^{\prime}} \neq \pi_{i}, \quad(i=1,2, \cdots, m),
\end{gathered}
$$

where $p_{1} \neq\left(\pi_{1}\right)=1$;

$$
\begin{gathered}
\sum_{j_{1}=1}^{t} a_{j_{1} j}^{t} p_{j_{1}}^{t}+\sum_{j_{2}=1}^{p} a_{j_{2} j}^{p} p_{j_{2}}^{p}+\sum_{j_{3}=1}^{l} a_{j_{3} j}^{k} p_{j_{3}}^{k}+\sum_{i^{\prime}=1}^{m} a_{i^{\prime} j} p_{i^{\prime}}+\sum_{s=1}^{S} a_{s j} p_{s^{\prime}}+a_{u j} p_{u^{\prime}}=P_{j}^{k} \neq \Pi_{j}^{k}, \quad\left(j_{3}=1,2, \cdots, l\right), \\
\sum_{j_{1}=1}^{t} a_{j_{1} s}^{t} p_{j_{1}}^{t}+\sum_{j_{2}=1}^{p} a_{j_{2} s}^{p} p_{j_{2}}^{p}+\sum_{j_{3}=1}^{l} a_{j_{3} s}^{k} p_{j_{3}}^{k}+\sum_{i^{\prime}=1}^{m} a_{i^{\prime} s} p_{i^{\prime}}+\sum_{s=1}^{S} a_{s s} p_{s^{\prime}}+a_{u s} p_{i^{\prime}}=p_{s}^{m} \neq \pi_{s}^{m}, \quad(s=1,2, \cdots, S), \\
\sum_{j_{3}=1}^{k} D_{j_{3}}^{k} P_{j_{3}}^{k}+\sum_{i^{\prime}=1}^{m} D_{i^{\prime}} p_{i^{\prime}}+\sum_{s=1}^{S} D_{s}^{m} p_{s}^{m}=D^{k} \neq E \\
P_{j_{3}}^{k}=\frac{p_{j_{3}}^{k}}{\left(i+\mu_{j_{3}}+v_{j_{3}}\right)} \neq \Pi_{j_{3}}^{k}, \quad\left(j_{3}=1,2, \cdots, l\right) \\
p_{i} \neq \frac{p_{i^{\prime}}}{i},(i=1,2, \cdots, m) ; \quad p_{s}^{m} \neq \frac{p_{s^{\prime}}^{m}}{i}, \quad(s=1,2, \cdots, S) ; \quad p_{u} \neq \frac{p_{u^{\prime}}}{i} .
\end{gathered}
$$

